\title{
A MAI KOR KIHÍVÁSAI ÉS A RÁJUK ADOTT VÁLASZOK A GYÖRI TANÍTÓKÉPZÉS MATEMATIKA-, INFORMATIKA- ÉS TERMÉSZETTUDOMÁNYI OKTATÁSÁBAN
}

\author{
PETZ TIBORNÉ - PÁPAI BERNADETT - REIDER JÓZSEF \\ Széchenyi István Egyetem, Apáczai Csere János Kar \\ Természettudományi Tantárgy-pedagógiai Tanszék
}

A mai egyre gyorsuló világunkban mindenkinek meg kell tanulnia helytállni és benne tájékozódni. A tanulás napjainkban egy folyamatos intellektuális készenlét, amely segítségével az embernek képesnek kell lennie a munka világa aktuális igényeinek felismerésére. Tudásszükségletét ennek megfelelően kell alakítania, és folyamatos fejlődésre kell alkalmasnak lennie az egész életén át (Magyar, 2003). A tanítási-tanulási szokások megváltozása már a XXI. század küszöbén is megfigyelhető volt, az oktatásban részt vevőknek alkalmazkodniuk kell a megváltozott viszonyokhoz. A digitális oktatásra való megfelelő átállás napjainkban fontosabb, mint korábban bármikor.

Írásunkban igyekszünk bemutatni, hogy a megváltozott oktatási-tanulási kultúra, az új mintatantervek hogyan befolyásolták a győri tanítóképzésben a matematikai, informatikai és természettudományos képzés struktúráját, a tantervi változtatásokat és az oktatási módszereket. Több kihívással is szembe kellett néznünk az elmúlt években a tanító szakos hallgatók képzése során. Ilyen változások voltak a Képzési és Kimeneteli Követelmények miatti tantervi változtatások. Ezeknek a változásoknak a következtében Győrben a tanító szakon mintegy 25\%-kal csökkentek az óraszámok a matematika, informatika és a természettudományos képzés terén. Az óraszámcsökkenés során a tananyag és az alkalmazott módszerek újragondolására volt szükség. A hallgatók egyre kedvezőtlenebb tudása, attitűdje, tanulási kultúrája ellen is tenni kell, sajnos egyre kevesebb órában. Ehhez a sok kedvezőtlen változáshoz jött az idei és az elmúlt évben történt pandémia, ami azt okozta, hogy kontaktórák helyett online oktatásra kellett áttérni.

Mindezek olyan problémák, amellyel mindenki szembesült az országban, aki az oktatásban tevékenykedik, de arra törekedtünk Győrben, hogy a lehető legtöbbet hozzuk ki az adott helyzetből. A változtatások során figyelembe vettük az új információs és kommunikációs technikák (később IKT) didaktikai alkalmazási lehetőségeit is, de nem hanyagoltuk el, nem hagyhattuk ki a már jól bevált manipulatív eszközök bemutatását és azoknak a tanító szakos hallgatók oktatásában való felhasználási lehetőségeit sem. Jelen munkánk során bemutatásra kerülnek az elméleti bevezető után azok az ötletek, amelyek megvalósításra 
kerültek, és amelyeket ezután tervezünk bevezetni. Mindezekkel célunk az oktatás során a hallgatók motivációjának növelése, tanuláshoz való hozzáállásának, attitűdjének pozitív irányba való megváltoztatása.

A matematika, informatika és a természettudományos tárgyak keretén belül megvalósult és tervezett foglalkozások, feladatok bemutatása során nyilvánvalóvá válhat az olvasó számára az a cél, hogy mind a hagyományos, mind az IKT adta lehetőségeket kihasználva fejlesszük a hallgatókat, és mind szélesebb körű, integrált tudás elsajátítását tegyük lehetővé számukra, felkészítve őket a későbbi hivatásukra.

\section{Elméleti gondolatok}

\section{A 21. században felnövö generáció és ismeretszerzésük folyamata}

A digitális korszakban felnővő korosztályra az jellemző, hogy a diákok a gyors ismeretszerzést igénylik, és az internet korszakában számukra ez már egyértelmủ információs tér. A társas kapcsolatok, társas érintkezési szokásaik megváltoztak, és a közösséghez tartozást, a közösségi élményt közösségi portálokon, blogokon, hálózatszervezésen alapuló játékokban találják meg (Tari, 2010). Az egymás mellett, párhuzamosan múködő, úgynevezett multitask alkalmazásokban való eligazodás nem okoz nekik problémát. A programok azonnali, gyors elérését, a feladatok megoldásakor az azonnali megerősitést és jutalmazást várják el. Ma már a keresések során releváns találatok birtokában, egyszerűen jutnak hozzá információkhoz, hálózati kapcsolatok létesítésével könnyen osztják meg a megszerzett ismereteket. Az oktatás során viszont meg kell bizonyosodnunk, hogy a megfelelő IKT-kompetenciákkal rendelkeznek, és nem csupán a közösségi oldalak információmegosztó applikációival vannak tisztában. A meglévő informatikai tudásukra kell alapozni, hogy a számukra legjobban megfelelő oktatási környezet kialakítható legyen. Fel kell hívni a figyelmüket arra, hogy melyik internetes forrás hiteles, milyen ismeretre van szükségük.

A tanulás során a külvilág modellezésére van szükség, a tanulás során mentálisan történik meg a környezet lemodellezése. Az oktatás során ezen a mentális reprezentáción alakíthatunk, változtathatunk, világképet, világnézetet formálhatunk. A történelem során több oktatási paradigma is jelen volt. Vannak, akik a közvetlen ismeretátadásnak, mások a szemléltetésnek, míg megint mások a cselekedtetésnek tulajdonítottak nagyobb szerepet. A különböző pedagógiai irányzatok egymást váltva és egymást kiegészítve is léteztek, és ezekből újabb elméletek alakultak ki, például behaviorizmus, kognitivizmus vagy épp a konstruktivizmus. A folyamat itt nem állt meg, hiszen a tudásáramlás, tudásmegosztás új színterei jelentek meg a digitális kultúra, a digitális oktatás térhódításával. A legújabb 
hálózatalapú tanulási formák, például a konnektivizmus alkalmazkodnak a diákok ismeretszerzési, közösségszervezési formáihoz (Paavola \& Hakkarinen, 2005). Nemcsak az elsajátításon van a hangsúly, hanem a tudásalkotás, tudásmegosztás során egy közösen készített tartalom létrehozásában vesznek részt a tanulók. Ezen alkotások létrehozása együttmüködést vár el az oktatásban részt vevőktől. Komenczi Bertalan az e-learninggel foglalkozó egyik munkájában fogalmazza meg, hogy a legújabb didaktikai paradigma az informatika eszközeinek felhasználásával a tanítás és tanulás minden eddiginél hatékonyabb formáit, módszereit ígéri. Természetesen ehhez szükség van arra, hogy a hallgatók minél szélesebb körű módszertani felkészítést kapjanak az IKT-eszközök felhasználásának lehetőségeiről és az oktatási módszerekről (Komenczi, 2006).

A tanulás nem más, mint az új információk befogadása, amely a tanulási folyamatban négy lépésként - információ megszerzése, rendezése, tárolása, majd továbbítása - értelmezhető. A tananyag megismerése több forrásból történhet, a forrás lehet szöveg, kép vagy hang. A megszerzett új ismereteket a már meglévő tudásalaphoz kell kapcsolni, így az új ismeret könnyebben feldolgozható, rendezhető, és segíti a megértést. Gyakorlás és elmélyítés során az új ismeretek rögzítése, tárolása történik meg, de ezeknek az információknak mindenképpen teljesen megértetteknek kell lenniük, hogy a felidézés, reprodukálás, alkalmazás során ne következzenek be hibák. Az eredményesség és tartósság érdekében van szükség a többcsatornás elmélyítésre. Ilyen lehetőségek a megértett szöveg saját megfogalmazása; az összefüggések ábrázolása és a vázlatkészítés, továbbá a több tantárgyat összekapcsoló összefüggések felismertetése. Így a hosszú távra érvényes rögzítés biztosítható. A megtanult ismeretanyagból csak akkor lesz tudás, ha a begyakorlással alkalmazhatóvá válik. A tanulás minőségét meghatározó komponensek: a tartós figyelem, a koncentrálóképesség, az intellektuális készségek és a felhalmozott tudásalap. Az új ismeret befogadását, a tanulás útját könnyíthetik vagy nehezíthetik a témára vonatkozó válaszreakciók, a beállítódás, a fogadókészség vagy elutasítás; a nyitottság vagy annak hiánya. Az önálló tanulás feltétele a tanulni tudás, a motiváció, az önálló kritikus gondolkodás, a problémamegoldó képesség (Magyar, 2003). A természettudományos tárgyakhoz való hozzáállása a hallgatóknak nem nevezhető pozitívnak, ezért ezeknek a tárgyaknak az oktatásához még inkább szükséges a nagyfokú, minden területet érintő szemléltetések, fejlesztések megvalósítása.

\section{Szemléltetés és az IKT}

A szemléltetés mindig is központi szerepet foglalt el az oktatás során. Már Comenius is megfogalmazta didaktikai alapelvei között a szemléletesség fontosságát: „Szükséges, hogy a megismerés mindig az érzékszervekből induljon ki (semmi sincs ugyanis az értelemben, ami nem volt meg előbb az érzékekben). Mi más ez, mint az, hogy a tanítás ne a dolgok szóbeli elbeszélésével vegye kezdetét, hanem a reális megfigyeléssel? És végül, miután 
megmutattuk a dolgot, jöhet a bővebb magyarázat." (Comenius, 1992) A cél minél több érzékszerv bekapcsolása az elsajátítási folyamatba, az általánosítás, fogalomalkotás induktív megismerési úton történik. Nagyon fontos elvet fogalmazott meg, miszerint a külvilág közvetlen megismerése az első lépés, amit a megismerési folyamatokba be kell vonni.

A jelenkor oktatásában a frontális oktatás háttérbe szorul, a számítógépes hálózaton elérhető képzési formák vannak jelen, amelyek segítségével a tanítási-tanulási folyamatot hatékonyan segíthetjük, és a megfelelő ismeretátadási, tanulási módszerek birtokában megszerezhető a kellő tudás. Az új platformok segítségével, tudáscserén alapulva nem hierarchikus, hanem sokcsatornás, kollaboratív tanulásra ösztönözhetjük hallgatóinkat. A tanító szakos hallgatók számára azonban elengedhetetlen a manipulatív szemléltetés és oktatás módszereivel való ismerkedés is. Tehát a két oktatási forma nem egymást helyettesítve, hanem egymás mellett kell hogy szerepeljen a hallgatók oktatása során. Ehhez módszertani megújulásra van szükség. Interaktívabb technológiák segítségével növelhető a hallgató kontrollja, több alkalom adódik az ismétlési lehetőségekre a tanulási folyamatban.

A tanító szakos hallgatók hivatásukra való felkészítése során az új típusú tanuláselméleteknek megfelelően mi is arra törekszünk, hogy a frontális előadások számát csökkentve olyan új tevékenységeket alakítsunk ki, amelyek során a kiadott feladatokkal az egész oktatási folyamatot kívülről irányítjuk. Egyfajta aszinkron tanítás és oktatás valósul meg, legyen ez egy IKT segítségével megvalósuló oktatás vagy éppen a manuális szemléltetés, cselekedtetés, kísérletezés. Az ilyen típusú tanulás a tanuló számára közvetlen sikerélményt jelent, ami erősíti a tanulási motivációt, és ezáltal önálló tanulásra serkenti a tanulót. Olyan tevékenységek kellenek, amelyek felhasználhatók az önálló, egyéni és a csoportos tanulásra, illetve bemutatásra egyaránt, és amelyek jól alkalmazhatók a tanítandó anyag elö- és utófeldolgozására is.

A szemléltetés Dienes Zoltán nyomdokain haladva valósul meg intézményünkben mind a hagyományos szemléltetés, mind a digitális területeken. A digitális tananyag tervezése során nem hagyható figyelmen kívül, hogy a modulokra szabdalt tananyag jól tanulható legyen. A tanuló önállóan tanul, mondhatni kettesben van a tananyaggal, ezért a tananyagnak megfelelően motiválónak kell lennie. Azonban ebben az oktatási formában is szükség van olyan feladatokra, amelyeket együtt tudnak elvégezni. Egy online, csoportosan szerkeszthető beadandó során mindenki hozzátehet az adott termék elkészítéséhez. A kommunikáció, az együttmunkálkodás során az emberi kapcsolatok is fejlődnek. A saját közösségimédia-felület kialakítása lehetőséget teremt a hallgatóknak az egymással való kapcsolattartásra, a naprakész információáramlásra. A kombinált oktatási (blended-learning) modell nyújthatja ezt a közösségi élményt. Ebben a modellben a hagyományos tantermi oktatás és az internet, illetve a digitális média által nyújtott lehetőségeket együttesen alkalmazzuk. A hallgatók és a tanárok az órára való felkészülés vagy prezentáció készítése alatt is 
folyamatosan kapcsolatban lehetnek és kommunikálhatnak egymással egy közös felületen, a beadandó dolgozatokat is erre a felületre töltik fel. Erre azért is szükség van, hogy ne alakuljon ki a hallgatóknak olyan félelme, melyet egy korábbi kutatásunkban eredményül kaptunk, hogy a hallgatók az IKT-eszközök hátrányának tekintik az elmagányosodást, a társas kapcsolatok megszűnését (Petz \& Reider, 2021).

A digitális szemléltetés esetén is igaz, hogy a több érzékszervi csatornára történő együttes hatás a szemléltetés ősi eszköze, melyet a számítástechnika fejlődése tett teljessé és interaktívvá. A tananyag eredményes elsajátításához olyan programokat kell használni, amelyek a tanítási-tanulási folyamatot segítik. A mai generáció számára fontos, hogy a hagyományos oktatás keretein belül is a szöveges tartalmat minél változatosabban illusztráljuk, hogy ezzel elkerüljük az egysíkú közlést (Forgó, 2001). Igyekszünk elérni, hogy a hallgatók már ne csak passzív befogadóként, hanem aktív résztvevőként üljenek az előadásokon, ahol a kölcsönös kommunikáció elve mentén azonnal válaszolhatnak.

\section{Megvalósítás, oktatási ötletek}

\section{Online lehetöségek}

Az óraszámcsökkentések, tantervi átalakítások során is szem előtt tartottuk, hogy a végzős hallgatók alapos és biztos matematikatudással rendelkezzenek. A kor kihívásának megfelelően szerettünk volna olyan elemeket bevenni az oktatásba, melyek a digitalizáció világában felnővő új generációnak is érdekes és hasznos információkkal szolgálnak. A csökkent számú kötelező matematika tárgyak mellett a szabadon választható tantárgyakba építettük be a szemléltetést és az IKT-eszközökkel való bővebb ismerkedési lehetőségeket. A hallgatókat annak érdekében, hogy kikerülve az életbe magabiztosan használhassák ezeket a technikákat, megismertetjük különböző, az oktatásban használható programokkal, applikációkkal.

Ilyen például a LearningApps tananyagkészítő alkalmazás, amelyben számos feladattípus közül lehet választani, például sorba rendezés, akasztófa, párkereső, szókereső, számpiramis, stb. A hallgatóknak létre kell hozni egy választott tananyagrész feldolgozásához matematikai feladatokat tartalmazó tankockákat. A GeoGebra program segítségével a matematika és a természettudományos tárgyak oktatását segíthetjük, a tanulási folyamat hatékonyságát javíthatjuk, az órák játékosságát és élményszerűségét növelhetjük. Remek alkalom ez arra is, hogy a hallgatók térlátását fejlesszük, térszemléletüket javítsuk. A tudás ellenőrzésére használhatjuk az online tudásellenőrző és felmérő programokat, mint például a Redmenta és a Kahoot!. A hallgatók tudásának ellenőrzése könnyen elvégezhető, a tanár azonnali visszajelzést kap a munkáról, teljesítményről. Nemcsak számítógépről, hanem tabletről vagy 
akár mobiltelefonról is használhatók ezek a programok. A Kahoot! segítségével kvízeket lehet készíteni, megosztani és játékosan lejátszani. Egy-egy alkalommal használva az óra játékosabbá, hangulatosabbá tehető. Ezekkel a programokkal egy előadás frontális formája is megszakítható, a hallgatók figyelmét tesztelhetjük, hisz bármikor tehetünk fel kérdéseket az aktuális vagy éppen korábbi órák anyagával kapcsolatban.

További lehetőségként adódik a QR-kódok használata. Egy korábbi évben hallgatóknak készítettünk egy kincskereső versenyt, ahol QR-kódok segítségével irányítottuk őket weboldalakra, adtunk meg nekik matematikai feladatokat, vagy rejtettünk el GPS-koordinátákat. Így egy nagyon hangulatos versenyt sikerült megalkotnunk, a hallgatóknak szükség volt az együttműködési képességükre, miközben észrevétlenül tanultak. A Timetoastot, ami egy idővonal-készítő alkalmazás, felhasználhatjuk más tantárgy oktatása során. Többször alkalmaztuk már, mikor arra kértük a hallgatókat, hogy végezzenek kutatómunkát. Ilyen feladat volt egy-egy tudós életének bemutatása vagy a fejlődési folyamat szemléltetése a természettudományok területén. Ezzel a hallgatókat rávehettük az események rendezett, sorrendben történő felsorolására és annak megfelelő prezentálására.

\section{Szabadban való oktatás}

A digitális platformok hallgatókkal való megismertetése mellett figyelmet fordítunk arra is, hogy a hagyományos szemléltetés kereteivel is megismerkedhessenek. A jelenkori pedagógiai irányzatok között az élménypedagógia, a valóságalapú tanulás is tudatosan használja és ajánlja például a szabadban tanulást. A természetben eltöltött idő alatt az irányítatlan szabad, később irányított játékok előnyösek és szükségesek. A természetben eltöltött idő nélkül a gyermek egészsége károsodhat. Ez lehet szorongás, figyelemzavar stb. Dillon és munkatársai 1993 és 2003 közötti kutatások elemzésével a következő megállapításokat teszik: a diákok jobban emlékeznek ezekre a szabadtéri oktatási alkalmakra, csökken a hiányzások száma, jobb eredményeket érnek el olvasásban, természettudományokban, matematikában (Dillon, és mtsai., 2006).

Jó eredményeket érhetünk el a megfelelő előkészületekkel, továbbá fontos a tantermi utómunka, melynek során a feldolgozás történik meg és a kapcsolatkeresés a kinti és benti tananyag között. A közvetlen érzékszervi tapasztalás, illetve az, hogy a hallgatóknak beleszólása lehet a tanulási folyamatba, már javít a tárgyhoz való hozzáálláson. Fontos, hogy ezekben az esetekben minél kevesebb papírmunkára legyen szükség. A hallgatóknak meg kell tanulniuk, hogy a tanító legyen magabiztos a kinti környezetben is. A szabadtéren való tanulásra olyan témákat, tananyagrészeket kerestünk, melyek tanítása jó gyakorlatokként alkalmazható, és amelyeket a hallgatók a későbbi hivatásukban is fel tudnak használni. Ezekkel az ötletekkel, foglalkozásokkal nyomatékosíthatjuk bennük, hogy a matematika olyan tudomány, amelyet alapszinten a tanulók egész életük során használni fognak. Ezért 
fontos, hogy megszerettessük velük, olyan példákat, feladatokat adjunk, melyek kapcsolódnak a hétköznapi dolgokhoz, például a kerthez, a környezethez. Márpedig a természet vagy a kert rengeteg alkalmazott matematikát kínál. Néhány példát sorolunk fel, amelynek inspirálója a Kř́ížféle kézikönyv (Kříž , 2017).

Feladatot adhatunk a hallgatóknak, hogy formákat, alakzatokat, testeket keressenek a kertben, vagy épp méréseket végezhetnek. Amennyiben jövőbeli hivatásuk során kirándulnak a gyerekekkel, adhatnak feladatokat is nekik. Hozzanak $1 \mathrm{~m}$ hosszú botot, keressenek 1 kg tömegű követ! Becsüljék meg az 1 percet! Mennyi a levegő hőmérséklete? De ahhoz, hogy ilyen feladatokat majd ők is adhassanak a gyerekeknek, a mérésmetodikával tisztában kell lenniük, saját maguknak is tudniuk kell a mennyiségi viszonyokat. A mértékegységek tanulásának fontos lépése, mikor elmagyarázzuk a gyerekeknek, hogy miért kell az önkényes mértékegységekről SI-mértékegységekre áttérni. Ehhez is gyüjthetnek tapasztaltot a természetben. Becsültessük meg, majd méressük is le, milyen széles a kézilabdapálya, ahol egység lehet az tyúklépés, lépés, fadarab, majd a szabvány méterrúd (1. ábra)!

A manapság oly nagy sikernek örvendő iskolakertek tervezésébe is bele lehet csempészni a matematikát, hiszen télen megtervezhetjük kicsinyített változatban papíron, amit tavasszal megvalósítunk a szabadban. A tervezést követően a palánták darabszámát és a megvételükhöz szükséges pénzügyi keretet is kiszámoltathatjuk. Gyermekeknél ezzel a pályaválasztást is segíthetjük, hiszen tervezések hatására kaphatnak kedvet a kertépítő mérnök szakhoz vagy akár a különböző pénzügyi, statisztikai számítások során a gazdasági pályákhoz. További téma, mely szintén szabadban játszásra ad lehetőséget, a szimmetriák tanítása.

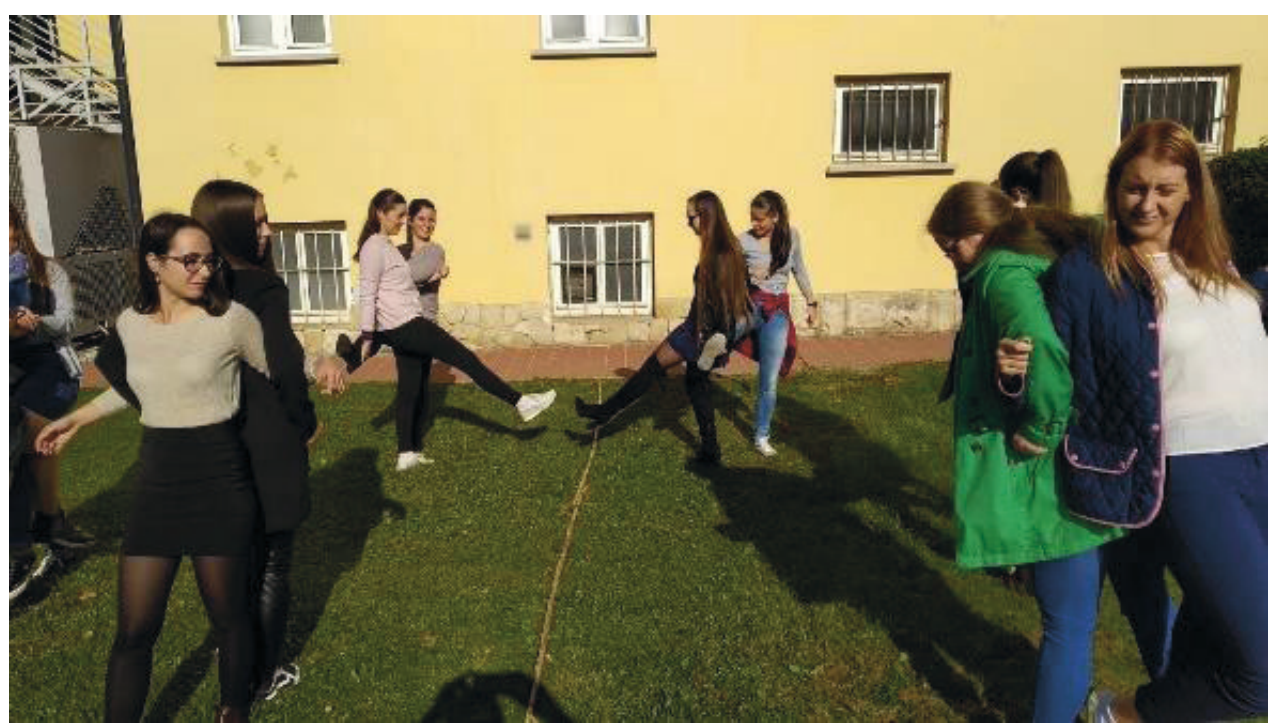

1. ábra. Játékos matematikaoktatás 
Más természettudományi ág, például a fizika oktatásához is segítségül hívhatjuk a körülöttünk lévő dolgokat. Kavicsot dobva a kerti tóba a hullámok keletkezését figyeltethetjük meg, vagy ha egy egyenes falú, hengeres vödröt megdöntünk, akkor a vízfelszín ellipszis alakú lesz. Ha az öntözőcsőből ferdén felfelé engedjük a vizet, akkor a vízsugár pályája parabola lesz. Egyre több olyan, a fizika határtudományaihoz tartozó természeti jelenség létezik, amely kiszorult az iskolai oktatás kereteiből, ugyanakkor hétköznapi világunk része. Ezek tárgyalása sok esetben szintén megoldható a természetben.

Hallgatóinkkal projektfeladatokat is végeztettünk már. Ilyen volt például egy napóra elkészítése. Ehhez utánajárásra, kutatómunkára volt szükségük. Nekik kellett megismerkedni a napóra működésével, beszerezni az elkészítéséhez szükséges anyagokat. Ez is egy olyan jó gyakorlat, amikor kikerülhetnek az olykor monotonná váló frontális oktatásból, és a magukénak érezhetik azt a terméket, amelyet a saját kezükkel alkottak.

A földrajz tantárgynál is elengedhetetlennek tartjuk, hogy a hallgatóinkat kivigyük a szabadba (2. ábra). Különösen a természetföldrajzi ismeretek taníthatók eredményesen az iskolai tantermen kívüli, külső helyszíneken, természetes környezetben, legyen szó ásvány- és kőzettani, geológiai alapfogalmak tanításáról, a nemzeti parkokban megőrzött természeti környezet jellemzőinek oktatásáról vagy a csillagászati földrajz oktatásáról. Például a matematika és a földrajz együttes tanítására korábban már megvalósítottunk

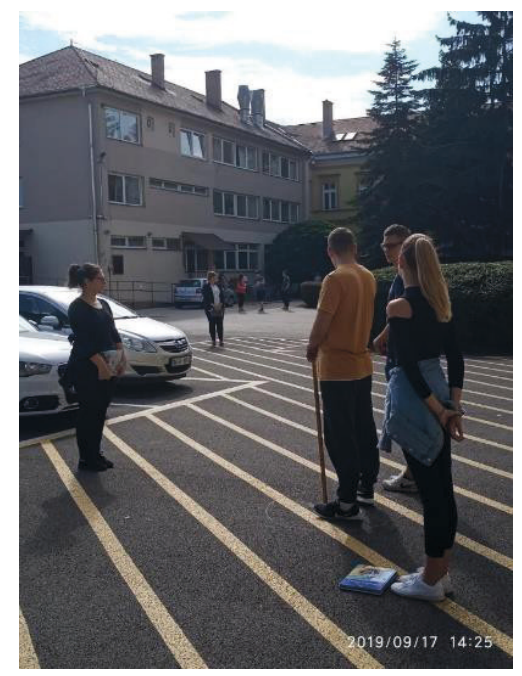

2. ábra. A Naprendszer szemléltetése ilyen típusú feladatokat. A csillagászati földrajz iránt általában nagyon érdeklődnek a tanulók. Nehézséget okoz azonban számukra, hogy megértsék azokat az óriási távolságokat, amelyek a világegyetemben, de még a Naprendszerben is jellemzőek. A szabadban könnyen modelleztük a Naprendszert a hallgatókkal, de előbb méretaránnyal kiszámoltuk a távolságokat. Ha 1 millió km-t 1 cm-nek tekintünk, akkor a Föld Naptól mért 150 millió km-es távolságának 1,5 m felel meg. Azonos mértékü kicsinyítéssel a Naphoz legközelebbi bolygó, a Merkúr $58 \mathrm{~cm}$-re lesz a Napot megszemélyesítő hallgatótól, a Naprendszer legtávolabbi bolygója, a Neptunusz pedig 45 m-re. Az egyes bolygókat a tanulók személyesítették meg, és így a Nap körüli keringés bemutatásához éppen egy futballpályányi terület volt szükséges.

Másik érdekes feladat, amit most bemutatunk, a földtörténeti korok szemléltetése (3. ábra). Ennek a témának a szemléltetéséhez is nagy térre van szükség. A Föld 4,6 milliárd éves történetét szintén „lekicsinyíthetjük”. A szemléltetés során a hallgatók könnyen 
megfigyelhették, hogy a leghosszabb földtörténeti idő az ősidő, megállapíthatták továbbá, hogy mikor következtek be például különböző hegységképződési folyamatok. Elhelyezhették a földtörténet megfelelő korszakában az őshüllők időszakát vagy akár a jégkorszakokat a pleisztocénben. A hallgatók így felismerhették, hogy az emberiség egész történelme csak az utolsó 1-2 cm-t foglalja magában. Így jobban érthetővé válhat számukra az az óriási időtávlat, amely a Föld teljes történetét magába foglalja (Halbritter, Reider, Pápai, \& Petz, 2020).

A fényképek a győri Széchenyi István Egyetem Apáczai Csere János Kar épületének udvarán készültek a másodéves tanító szakos hallgatók lelkes közreműködésével.

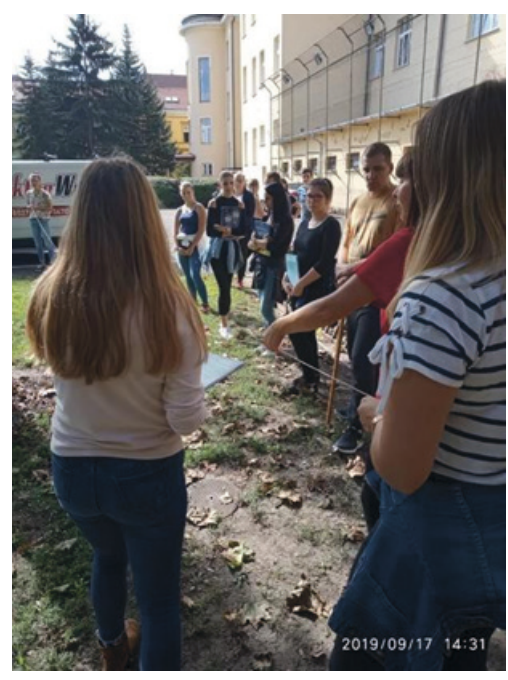

3. ábra. Földtörténeti korok szemléltetése

\section{Osztályteremi gyakorlatok}

A digitális és a szabadtéri feladatok bemutatása után kerüljön sor néhány, a tanteremben elvégezhető módszertani feladatra, melyekkel célunk, hogy a digitális eszközök alkalmazása ne legyen túlzott, hiszen az veszélyeket is rejt. El kell magyarázni a hallgatóknak, hogy mik a pozitív példák; ismertetni kell az általuk kitűzött és megvalósított célokat. Ugyanakkor tudatosítani kell bennük, hogy ha nem megfelelően kidolgozott digitális anyagokat használnak, akkor azok károsak is lehetnek. Valamint újra megjegyezzük, hogy a tantervekben az óraszámcsökkentés szintén veszélyeket hordoz magában, hiába a korszerü technika újdonsága. Éppen ezért készítünk a kurzusok során hagyományos szemléltetőeszközöket, miközben megbeszéljük, hogy miért fontosak ezek, valamint milyen problémákat oldhatunk meg a segítségükkel.

Kisiskoláskorban és fiatal felnőttkorban is igaz a következő idézet, miszerint „ha hallom, elfelejtem, ha látom, megjegyzem, ha csinálom, megértem”. Ezért van tehát arra szükség, hogy a tanítóképzős hallgatók oktatása során is előtérbe kerüljön az önálló cselekvés útján való ismeretszerzés. A szemléltetés megalapozza a fogalomalkotást, segít a tevékenység elsajátításában, rámutat a különböző gyakorlati alkalmazási lehetőségekre. Egy-egy fogalom osztályozásában, rendezésében nagy szerepe van, és a tanultak alkalmazását is segítheti. Korábbi vizsgálatainkban (Petz, 2019) azt tapasztaltuk, hogy a geometria témakör okozza a hallgatóknak a legtöbb problémát tanulmányaik során. Törekszünk arra, hogy feladatokon keresztül például a nagyságrendi viszonyokkal is megismerkedjenek a hallgatók. Tevékenységeken keresztül sajátítsák el a képleteket, levezetési módszereket, így a hibák 
szemléltetéssel, önálló tapasztalatszerzéssel javíthatók. A módszertan-, tantárgypedagógia-órákon a hallgatókat megismertetjük a hagyományos szemléltetőeszközökkel, melyekkel nagyon sok fajta témakörben feladatokat végezhetnek, miközben a közoktatásból hozott hiányosságokat, elmaradásokat pótolhatjuk, javíthatjuk. A kötelező oktatás keretein belül megismertetjük a hallgatókat a következő eszközökkel (4. ábra):

\section{építőkocka}

- Térlátás fejlesztés

\section{színesrúd}

- Számfogalom

- Múveletek

- Geometria

- Törtek

- Statisztika

\section{logikai készlet}

- Logika

- Halmazok

- Geomtria

\section{geometriai építőkészlet}

- Testek elnevezései

- Geometriai tulajdonságok

- Kémiából molekulák térbeli szemléltetése

\section{4. ábra. Hagyományos szemléltetöeszközök}

Megismertetjük őket az eszközök használati lehetőségeivel, oktatási módszertanukkal. Hallgatóink kreativitását fejlesztve minden évben feladatul adjuk a saját szemléltetőeszköz készítését, ami több célt szolgál. Az eszközök készítésekor a hallgatók elmélyednek egy-egy tanult témakörben, valamint el kell magyarázniuk, hogy milyen témában és hogyan lehetne tanítani az adott eszköz segítségével. Miközben bemutatják az eszközöket, a kérdésfeltevést, utasításadást és gyakorolhatják. Néhány példa hallgatói eszközökre (5. ábra): 

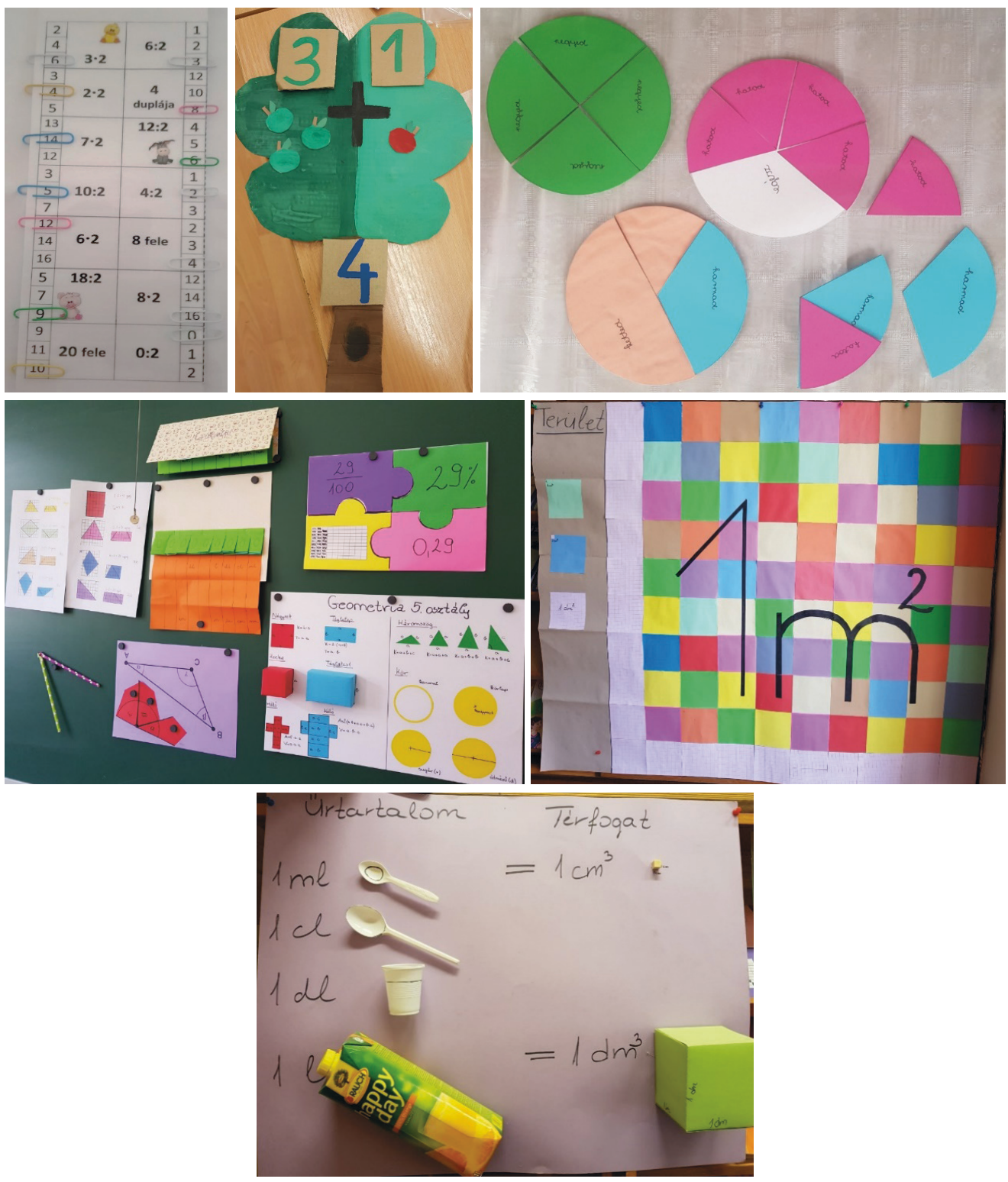

5. ábra. Néhány példa a hallgatói taneszközökböl

De a hallgatók otthonában fellelhető játékokról sem feledkezünk meg. Ilyen például a legó alkalmazása. Karunkon 2019-ben digitális játékpedagógiai stúdiót adtak át azzal a céllal, hogy egy olyan szakmai műhely jöjjön létre, ahol a legókkal játszva játékosan lehet tanulni és közösségteremtő módon alkotni. A hallgatók és a gyermekek a teremben ezek 
mellett a robotizáció elméleti és gyakorlati sajátosságaival is megismerkedhetnek. A matematika szinte minden témakörében alkalmazható a legó az elsajátítási folyamatban. Sajnos egyre többször szembesülnek a hallgatók azzal, hogy az osztályokban, ahol később tanítani fognak, egyre több a tanulásban akadályozott kisgyermek. Az ő oktatásuk során a minél fejlettebb módszertani felkészülés elengedhetetlen (6. ábra). Ehhez is jó segítség a legó.
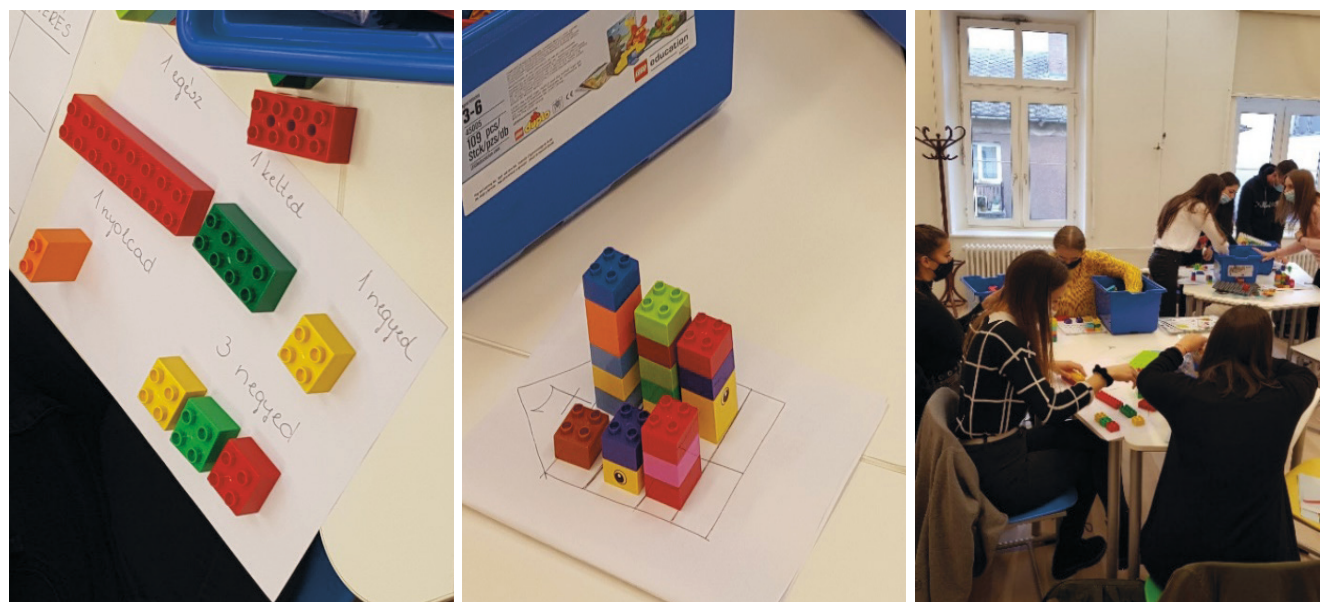

6. ábra. Foglalkozások a Lego-teremben

\section{Összegzés}

Az új kihívások által elénk állított problémák megoldásának keresésekor azt mondhatjuk, hogy a régi pedagógiai eszköztárat nem szabad teljesen eltörölni, hanem bővíteni kell az új technikai vívmányokkal, és segítségükkel a motiváltságot, együttműködést, kommunikációt, kreativitást, vagyis az úgynevezett soft skilleket kell az oktatásba megfelelően integrálni. A digitális eszközök önmagukban nem fogják megújítani az oktatást. Nemcsak új eszközökre, hanem új gondolkodásra is szükség van. Az új módszerek integrálása révén a formális oktatás mellé be kell hozni a nem formális és az informális tanulás kereteit is. A hármas egység segítségével elérhető, hogy a tanár a katedrán még az előadások során se alkalmazza mindig a frontális munkát, hanem egyfajta tanulást irányító személlyé változzon. A fentebb említett digitális és hagyományos ötleteket megvalósítottuk a hallgatók oktatása során az előadások és a gyakorlatok keretében, amennyire a tantermi keretek és az eszközpark megengedte.

Igyekszünk minél inkább a hallgatói kísérletező-felfedező kíváncsiságra hatni csoportmunkával, páros munkával, tanítva tanulással, mikrotanítással, esetleg projektjellegű oktatással. Így a digitális világ térhódítása mellett megtartjuk a hagyományos oktatás 
pozitívumait is, és a hallgatóknak a matematika és a természettudományok iránti negatív attitűdjét motiválással, együttműködéssel és pozitív kommunikációval igyekszünk megváltoztatni. A matematika területén tett korábbi vizsgálataink igazolják tevékenységünket (Petz, 2019). A hallgatók tudásának felmérésekor az eredmények mind számszerűleg, mind a kérdőíves vizsgálatokra adott szöveges válaszok alapján azt mutatják, hogy a hallgatók tudása (mintegy 60\%-kal) és hozzáállása is pozitívan változik. Véleményünk szerint a többi terület felmérésekor is ezt tapasztalnánk. Ez későbbi vizsgálatunk tárgyát jelenti. A sok feladat és munkáltatás során felkészülnek jövőbeli hivatásukra, nem fogja őket olyan erősen érinteni az úgynevezett „valóságsokk” jelenség.

\section{Felhasznált irodalom:}

Comenius, J. (1992). Didactica magna (Nagy oktatástan). Pécs: Seneca Kiadó p. 287.

Dillon, J., Rickinson, M., Teamey, M., Morris, M., Choi, M. Y., Sanders, D., \& Beneield, P. (2006). The value of outdoor learning: evidence from research in the UK and elsewhere. School Science Review 87: 320-323.

Forgó, S. (2001). A multimédiás oktatóprogramok minöségének szerepe a médiakompetenciák kialakitásában. Új pedagógiai szemle. 2001/7-8. Letöltés dátuma: 2021. január 22, forrás: https://folyoiratok.oh.gov.hu/uj-pedagogiai-szemle/a-multimedias-oktatoprogramokminosegenek-szerepe-a-mediakompetenciak

Halbritter, A., Reider, J., Pápai, B., \& Petz, T. (2020). A szabadban tanulás lehetöségei néhány tantárgy oktatásában (A XXIII. Apáczai-napok Tudományos Konferencia tanulmánykötete kötet). (A. Makkos, Á. Fehér, \& A. Pongrácz, szerk.) Győr. Letöltés dátuma: 2021. január 23, forrás: https:/lib.sze.hu/images/Apaczai/kiadv\%C3\%A1ny/ 2019/Ap\%C3\%A1czai\%20napok_tanulm\%C3\%A1nyk\%C3\%B6tet_0504_ Halbritter\%20Andr\%C3\%A1s\%20\%C3\%A9s\%20mtsai.pdf

Komenczi, B. (2006). Az E-learning lehetséges szerepe a magyarországi felnöttképzésben. Budapest: Nemzeti Felnőttképzési Intézet. Letöltés dátuma: 2021. január 23, forrás: https://konyvtar.nive.hu/files/03_komenczi.pdf

Kříž , M. (2017). Zahrada, která učí. (cseh nyelven, A kert, ami tanít). Kněžice (CZ): Chaloupky.

Magyar, E. (2003). Bekezdések a tanulásról (Az e-learning szerepe a felnőttoktatásban és -képzésben. kötet). (H. L.-K. Gitta:, Szerk.) Budapest: Érdi Rózsa Nyomda.

Paavola, S., \& Hakkarinen, K. (2005). The Knowledge Creation Metaphor - An Emergent Epistemological Approach to Learning. Science \& Education 14(6) : 535-557. Forrás: https://bit.ly/3p6dESH https://doi.org/10.1007/s11191-004-5157-0 
Petz, T. (2019). Kompetencia alapú oktatás megvalósulása és kritikus pontjai a tanitóképzésben. Eger: Doktori Disszertáció.

Petz, T., \& Reider, J. (2021). A tanító szakos hallgatók IKT ismeretei a matematika oktatásában. Tudásmenedzsment 21, 1-2 pp. 210-220. 11 p. https://doi.org/10.15170/TM.2020.21.1-2.17

Tari, A. (2010). Y generáció Klinikai Pszichológiai jelenségek és társadalomlélektani összefüggések az információs korban. Budapest: Jaffa Kiadó. 